УДК 94(599) + 94(510.2)

DOI 10.25205/1818-7919-2021-20-1-46-56

\title{
The Gradual Softening of the Philippines' Hedging Strategy towards China under President Duterte
}

\section{A. Gerstl}

Palacký University

Olomouc, Czech Republic

Abstract

Under President Rodrigo Duterte, in office since 2016, the Philippines' traditional hedging strategy towards China gradually softens. Due to Chinese investments as part of the Belt and Road Initiative (BRI) the relations have become closer, while security relations with the United States remain strained. The ongoing territorial dispute in the South China Sea and the negative perceptions of the Philippine citizens on China, however, serve as a corrective for strong bandwagoning with China.

Keywords

The Philippines, China, hedging, bandwagoning, Belt and Road Initiative, South China Sea

Acknowledgements

This study was funded by "Supporting the International Mobility of Researchers - MSCA-IF at Palacký University Olomouc" (CZ.02.2.69/0.0/0.0/18 070/0010285)

For citation

Gerstl A. The Gradual Softening of the Philippines' Hedging Strategy towards China under President Duterte. Vestnik NSU. Series: History and Philology, 2021, vol. 20, no. 1: History, p. 46-56. DOI 10.25205/1818-7919-2021-20-146-56

\section{Постепенное смягчение стратегии сдерживания Филиппин в отношении Китая при президенте Дутерте}

\section{А. Герстль}

Университет Палаикого

Оломоуи, Республика Чехия

\section{Аннотаиия}

Стратегия сдерживания - популярное направление современной мировой политики, которое позволяет более слабым державам сохранять баланс между конфронтацией и сотрудничеством при взаимодействии с сильными державами. Цель данного исследования - установить, придерживаются ли Филиппины этой стратегии в отношениях с Китаем после прихода к власти Родриго Дутерте в 2016 г. Китайско-филиппинские отношения рассматриваются в системе, которая включает также две страны - США и Японию - в качестве противовеса. Такой подход позволяет взглянуть на проблему с точки зрения сравнительной перспективы, а также демонстрирует возможности для стратегического маневра, которые есть у Филиппин. Главной причиной напряженных отношений Китая и Филиппин является территориальный спор за риф Мисчиф в Южно-Китайском море, который в 1994 г. был взят Китаем под военный контроль. После победы на президентских выборах в 2016 г. Родриго Дутерте внешнеполитический курс Филиппин коренным образом изменился. Антиамериканская риторика избранного президента привела к видимому ослаблению сотрудничества с США в сфере безопасности. На фоне охлаждения отношений с одним из ключевых партнеров Филиппин Дутерте взял курс на укрепление сотрудничества с Китаем, особенно в экономической сфере. Благодаря китайским инвестициям в рамках ини- 
циативы «Один пояс, один путь» на Филиппинах была запущена серия масштабных инфраструктурных проектов. Вышеописанные факты создают ложное впечатление о резкой переориентации Филиппин на антизападный курс после выборов 2016 г. Тем не менее территориальный спор и связанное с ним негативное отношение филиппинских граждан к Китаю служат факторами, корректирующими внешнюю политику правительства Дутерте. Достаточно сказать, что Филиппины продолжают получать существенные инвестиции от США и укрепляют связи с Японией как в экономической сфере, так и в сфере безопасности, а также периодически вступают в дипломатическую конфронтацию с Китаем.

Ключевые слова

Филиппины, Китай, стратегия сдерживания, стратегия примыкания, инициатива «Один пояс, один путь», Южно-Китайское море

Благодарности

This study was funded by "Supporting the International Mobility of Researchers - MSCA-IF at Palacký University Olomouc" (CZ.02.2.69/0.0/0.0/18_070/0010285)

Для изитирования

Gerstl A. The Gradual Softening of the Philippines' Hedging Strategy towards China under President Duterte // Вестник НГУ. Серия: История, филология. 2021. Т. 20, № 1: История. С. 46-56. DOI 10.25205/1818-7919-202120-1-46-56

Since the launch of the Belt and Road Initiative (BRI) in autumn 2013, this ambitious Chinese infrastructure and connectivity scheme has raised, in many participant countries, both hopes and fears; hopes of acquiring economic benefits from China and fears of growing Chinese economic and political influence in their countries. In Central Asia, for instance, there is evidence for the increase of Sinophobe sentiments among ordinary citizens, while the elites continue to promote economic engagement with the People's Republic of China (PRC). The perceptions on China recently became more critical in Southeast Asia [Gong, 2019. P. 642-647]. Whether China's medical diplomacy to support nations that are severely affected by the Coronavirus pandemic - a new kind of soft diplomacy - is able to improve its image or not, remains to be seen. The promotion of the Health Silk Road as part of the BRI is a deliberate political move of the Chinese President and Secretary General Xi Jinping to improve China's international image.

Both the land-based Silk Road Economic Belt (SREB) and the $21^{\text {st }}$ Century Maritime Silk Road (MSR) pass through Southeast Asia, making it a key region in the BRI. Beijing has close economic ties with the Association of Southeast Asian Nations (ASEAN) and its ten individual members. The political relations, however, are overshadowed by the unresolved territorial dispute in the South China Sea. The South China Sea is a globally important sea line of communication, also rich in oil and gas resources as well as fish. China, Taiwan, Brunei, Malaysia, the Philippines and Vietnam have overlapping claims. Since 2008/09, tensions in the South China Sea have increased due to China's growing assertiveness, notably the building of artificial islands and their militarization, regular surveillance activities in the Exclusive Economic Zones (EEZ) of Malaysia, the Philippines and Vietnam as well as the refusal to accept the award of the Arbitral Tribunal of the Permanent Court of Arbitration of July 2016 [Gerstl, 2017] ${ }^{1}$.

A country in which China has a very negative image is the Philippines. In the presidential elections in May 2016, a majority of the Philippine electorate (39 per cent) voted for Rodrigo Roa Duterte. During the electoral campaign Duterte made contradictious statements concerning his future policies towards China: on the one hand, in line with the majority sentiments of the voters, he portrayed himself as being tough on Manila's territorial claims in the South China Sea. He even vowed to ride a jet ski to the Spratly Islands and plant the Philippine flag there. On the other hand,

${ }^{1}$ Hayton B. The South China Sea - "The Status Quo is not the Worst Situation". Interview with A. Gerstl, and R. Fürst // Central European Institute of Asian Studies (CEIAS). 2019. URL: https://ceias.eu/the-south-china-sea-thestatus-quo-is-not-the-worst-situation/ (accessed 29 April 2020). 
Duterte did signal openness for bilateral talks with Beijing on the South China Sea in exchange for loans and investments which the Philippines requires ${ }^{2}$.

This contribution argues that while the BRI could become a catalyst for closer economic relations of the Philippines with China, the unresolved South China Sea dispute poses a major security risk that undermines the whole relationship. The research question asks whether the Philippines, under the presidency of Rodrigo Duterte, is still applying a hedging strategy towards Beijing. The aim of this strategy is to provide insurance against risks stemming from China's behaviour, notably in the South China Sea, but also to benefit from opportunities offered by China's economic rise. The article starts with a brief discussion of the concept of hedging, followed by an assessment of the relations of the Philippines with China and, to a lesser extent, the United States (US) and Japan. Subsequently, the hedging components will be applied to assess the relations of the Philippines with China since 2016. Finally, a conclusion will be drawn.

To respond to China's economic and military rise, many nations, notably in Southeast Asia, apply a hedging strategy. Even though, or maybe exactly because, hedging is a fashionable concept in International Relations (IR) theory, there is a great amount of confusion about hedging in literature. The reason is that instead of an undisputed definition there exist many rivaling interpretations [Haacke, 2019. P. 377-381]. Basically, hedging can be understood as a middle position between pure-balancing and pure-bandwagoning [Goh, 2006. P. 1], two ideal-typical neorealist strategies [Waltz, 1979]. Through hedging a weaker power aims at insuring itself against risks posed by the behaviour of a greater power. In accordance with Kuik [Kuik, 2008. P. 171], this contribution does not restrict hedging to mitigating risks. It argues that the second key aim of hedging is to reap diplomatic, economic and/or security benefits from its relations with the hedging target.

A hedging strategy therefore reflects a mix of cooperation and confrontation applied by the weaker power in its relations with the greater power. This contribution utilizes a simplified hedging framework which builds on Kuik [Kuik, 2008; 2016]. It applies four key components of a hedging strategy, namely perceptions on the hedging target, engagement, limited balancing and limited bandwagoning. The component perception is an innovation made by the author, based on the notion that how a hedger perceives the opportunities and risks stemming from the relations and behaviour of the hedging target is crucial for deciding on the specific hedging policies [Hiep, 2013. P. 337]. For instance, if the hedging target poses a perceived security risk, depending on internal and further external circumstances, either a balancing or bandwagoning reaction can be expected. The component engagement comprises of political, diplomatic and economic relations. Balancing can be further distinguished in internal and external balancing. While the former refers to the self-help capabilities of a nation, the latter covers security partnerships and cooperation with other actors. In its pure form, bandwagoning refers to "aligning with the source of danger" [Walt, 1987. P. 17]. Limited bandwagoning happens, if a weaker power coordinates certain policy issues with the hedging target [Kuik 2008. P. 168-169].

In this contribution, the analysis of the Sino-Philippine relations is embedded in an assessment of the Philippines' ties with China as well as the US and Japan. To include the relations with two potential counterweights to China is important due to two conceptual reasons: firstly, it puts relations with the hedging target, China, in a comparative perspective. Secondly, it reveals whether the Philippines has counter-balancing options at all.

The Philippines is a middle power with a population of 105 million and a comparatively weak military ${ }^{3}$. With a GDP of 330 billion USD (2018), it is regarded as a lower middle income country with a highly uneven income distribution. In the Human Development Index (HDI) 2019, the Philippines is ranked 106 out of 189 countries. The country is indebted, has a budget deficit and requires foreign capital and knowhow. Moreover, the socioeconomic development is severely ham-

\footnotetext{
${ }^{2}$ Rodrigo Duterte interview: Death, drugs and diplomacy // Al Jazeera. 2016. 16 October. URL: https://www. aljazeera.com/programmes/talktojazeera/2016/10/exclusive-rodrigo-duterte-war-drugs-161015100325799.html (accessed 20 April 2020).

${ }^{3}$ Asia Power Index // Lowy Institute. URL: https://power.lowyinstitute.org/ (accessed 3 May 2020).
} 
pered by a poor infrastructure. For instance, despite being an insular nation comprising of 7000 islands, the port of Manila is only the $30^{\text {th }}$ largest in the world. The country is also a flawed democracy with the president as the political key actor. Duterte who still enjoys approval ratings of 80 per cent was able to strengthen his "illiberal populist rule" in the mid-term elections in $2019^{4}$.

As the analysis of Duterte's statements reveals, the president is aware of China's power and the Philippines' limited influence and strategic options in the international system. He also views possible negative consequences of a stronger military engagement of the US in the Indo-Pacific in regard to causing a conflict with the PRC. Without labeling him a "neorealist", the assessment shows that his perceptions resemble a neorealist understanding of international relations. However, the power asymmetries in international politics are not the only lens for interpreting Duterte's view on the great powers, notably the US. His personality and personal experiences are also important for understanding his foreign policy strategy. Duterte is a former long-time mayor of Davao in Southern Mindanao and an outsider in the Philippine's political system that is dominated by traditional family clans. His anti-Americanism builds, inter alia, on his leftist attitudes, negative views of US colonialism, a belief of negative US involvements in affairs in Mindanao and Washington's criticism on his war on drugs ${ }^{5}$. The latter has been criticized internationally, notably the killings of suspected drug dealers and innocent people [Johnson, Fernquest, 2018].

In October 2016, Duterte spectacularly declared the Philippines' military and economic "separation" from the US. Thereby he stressed his partnership with Beijing and the aim of seeking closer relations with Moscow ${ }^{6}$. In line with this re-orientation is that he ridiculed his jet ski announcement made during the presidential campaign as a joke ${ }^{7}$. Duterte even declared that he would "shut up" about the South China Sea dispute, if Beijing funds a railway connection between Manila and Mindanao, investing 4 billion USD ${ }^{8}$. Comparable to Malaysia's former Prime Minister Mahathir Mohamad, Duterte often generalizes China's actions as typical great power behaviour. He claims that the actions in the South China Sea are part of a "greater game of geopolitics", "not directed" at the Philippines ${ }^{9}$.

Duterte's objective is to shift from the traditional pro-Western foreign policy to a more independent course. However, he also emphasized the importance of maintaining friendly relations with all partners ${ }^{10}$. In later statements made after the election of Donald Trump as US president, Duterte said that he has "nothing against America" and even called Trump "my friend" 11.

As contradictious as these statements sound - and notwithstanding his often rude remarks and verbal insults, Duterte's perceptions of China and the US expressed in selected interviews and speeches are surprisingly consistent. (However, a caveat is that the number is comparatively small and only English sources could be ascertained.) Whether his statements reflect the actual hedging strategy of the Philippines against China will be examined below.

\footnotetext{
${ }^{4}$ Thompson M. R. Who Will Win the Philippines' Midterm Elections? // The Diplomat. 2019. 29 April. URL: https://thediplomat.com/2019/04/who-will-win-the-philippines-midterm-elections/ (accessed 29 April 2020).

${ }^{5}$ Interview with Rodrigo Duterte // RTL. 2017. 22 May. URL: https://www.youtube.com/watch?v=Hf6f97X9ntA (accessed 15 April 2020).

${ }^{6}$ Rauhala E. Philippines' Duterte called for a 'separation' from U.S. He is now backtracking // Washington Post. 2016. 21 October. URL: https://www.washingtonpost.com/gdpr-consent/?next_url=https\%3a\%2f\%2f (accessed 17 May 2020).

${ }^{7}$ Rodrigo Duterte interview: Death, drugs and diplomacy // Al Jazeera. 2016. 16 October. URL: https://www. aljazeera.com/programmes/talktojazeera/2016/10/exclusive-rodrigo-duterte-war-drugs-161015100325799.html (accessed 20 April 2020).

${ }^{8}$ Sarmiento B. S. China leaves Duterte's dream train at the station // Asia Times. 2018. 10 October. URL: https:// asiatimes.com/2018/10/china-leaves-dutertes-dream-train-at-the-station/ (accessed 4 May 2020).

${ }^{9}$ Romero A. Duterte asks China: Don't touch Pag-asa Island // The Philippine Star. 2019. 6 April. URL: https:// www.philstar.com/headlines/2019/04/06/1907700/duterte-asks-china-dont-touch-pag-asa-island (accessed 21 April 2020).

${ }^{10}$ Exclusive interview: Philippine president on relations with China, US // CGTN. 2016. 18 October. URL: www. youtube.com/watch? $\mathrm{v}=$ liviotEMhEc (accessed 12 May 2020).

${ }^{11}$ Interview with Rodrigo Duterte // RTL. 2017. 22 May. URL: https://www.youtube.com/watch?v=Hf6f97X9ntA (accessed 15 April 2020).
} 
Despite its pro-Western orientation, the Philippines had already established diplomatic relations with the PRC in 1975. However, the Philippines still has no strategic partnership with China. At least since China occupied the Mischief Reef in 1994, the overlapping territorial claims in the South China Sea impact negatively on the bilateral relations. Former president Gloria Macapagal Arroyo (2001-2010) was criticized for becoming too close to the PRC, symbolized in joint infrastructure projects and the Joint Marine Seismic Undertaking (JMSU) in the South China Sea, together with China and Malaysia (2005-2009). Her successor Benigno Aquino III. (2010-2016) pursued "a proactive foreign policy, the centrepiece of which was the promotion of the Philippines' maritime interests and sovereign rights in the South China Sea" [Baviera, 2016. P. 202]. He implemented a dual internationalization strategy, simultaneously seeking international legal arbitration (initiated in January 2013) and deepening the relations with China-critical countries, notably the US and Japan [Gerstl, 2017. P. 211]. Ironically, his tenure expired two weeks before the Arbitral Tribunal of the Permanent Court of Arbitration (PCA) in The Hague released its favourable award in July 2016. The PRC refused to participate and regards the award as null and void. The award is strongly in favour of the Philippines, it notably rejects Beijing's nine-dash line, a claim based on "historic rights", as incompatible with the United Nations Convention on the Law of the Sea (UNCLOS). In addition, building on a complex legalistic, but convincing reasoning it stated that Mischief Reef, Second Thomas Shoal and Reed Bank form part of the Philippine EEZ [Permanent Court of Arbitration, 2016].

After assuming office of the President of the Philippines on 30 June 2016, Duterte pursued a surprisingly friendly policy towards China. Strikingly, he established a link between Chinese investments and Philippine concessions in the South China Sea [Baviera, 2016]. In addition, he never used the beneficial award of the Arbitral Tribunal to put diplomatic pressure on the PRC. Rather than balancing against China, Duterte sought to improve the bilateral relations through engagement, notably economic agreements and people-to-people contacts ${ }^{12}$. Shortly after his election he traveled to China where he secured large deals, worth 24 billion US Dollar, notably in the realm of infrastructure development; though not all deals materialized.

Many questions also remain concerning the scope and content of the Sino-Filipino Memorandum of Understanding (MOU) on cooperation in oil and gas development in the South China Sea that was signed during Xi's visit in November $2018^{13}$. The terms remain undisclosed, but Manila stresses that it does not impact on its sovereignty claims ${ }^{14}$. The joint development approach however, since the failure of the JMSU is contested in the Philippines.

In addition to Manila's bilateral ties with Beijing, ASEAN offers many multi- and bilateral venues for a regular exchange in different policy areas. Being the ASEAN country coordinator for the PRC (2018-2021) further institutionalizes the Philippines' contacts with China. Under Duterte, though, direct engagement with the two other key partners - the US and Japan - remains also very strong. The relations with Washington though, since 2016 have gone through many ups and downs. While the ties were strained with the Obama administration, they improved after the election of Donald Trump as US president. The US are still the main security guarantor for the Philippines, formalized in the Mutual Defence Treaty (MDT) of 1951. Manila and Tokyo signed a strategic partnership in 2009 which was upgraded to a strengthened strategic partnership in 2015. Building on existing excellent ties, Duterte managed to establish a sound working relationship with Prime Minister Shinzo Abe, reflected in many mutual visits.

${ }^{12}$ Pascual Jr. F. D. The Hague decision hangs over Duterte // The Philippine Star. 2019. 16 April. URL: https:// www.philstar.com/opinion/2019/04/16/1910401/tsgyR9MwvHiCfr3k.99 (accessed 15 May 2020).

${ }^{13}$ Batongbacal J. A Closer Look at China's Proposal for Joint Exploration with the Philippines // Asia Maritime Transparency Initiative (AMTI) Update. 2018. URL: https://amti.csis.org/closer-look-chinas-proposal-joint-explorationwith-philippines/ (accessed 29 May 2020).

${ }^{14} \mathrm{Ng}$ T., Zhen L. China and Philippines sign oil and gas exploration deal as Xi Jinping meets Rodrigo Duterte // South China Morning Post. 2018. 20 November. URL: https://www.scmp.com/news/china/diplomacy/article/2174213/chinaphilippines-sign-oil-and-gas-exploration-deal-xi-jinping (accessed 29 April 2020). 
Engagement of China, Japan and the US is also the pattern in the Philippines' economic relations. China is, similar to most other countries in Southeast and Northeast Asia, the Philippines' main trade partner. In 2018, the PRC had a share of 16.9 per cent (30.8 bil. USD), followed by Japan (11.6 per cent), the US (10.3 per cent) and the EU (c. 10 per cent). The trade deficit with China amounts to 13.2 bil. USD. Both trade mostly electrical and electronic products, transport equipment; the Philippines also exports many agricultural goods.

Manila requires foreign capital and knowhow for its socioeconomic development. Compared to other Southeast Asian nations, however, the Philippines attracts less foreign direct investment. Since 2013, the amount of FDI increased gradually from 3.9 to 9.8 bil. USD in 2018. The order of the top investors varies considerably in a year-to-year comparison. In 2019, Singapore was the main investor ( 3.5 bil. USD), followed by China (1.75 bil. USD) and South Korea ( 820 mil. USD) ${ }^{15}$. The US, Japan, the European Union and other ASEAN members, traditionally, are also significant investors.

Aware of the Philippines' infrastructural shortcomings, Duterte promotes "Build Build Build", an ambitious infrastructure program to upgrade or build roads, railways and ports (180 bil. USD from 2017 until 2022). The key partners for his "signature economic policy" are so far the PRC and Japan ${ }^{16}$. Duterte, who attended both BRI forums in Beijing and traveled several times to China between 2016 and 2019, repeatedly expressed his support for the BRI ${ }^{17}$. In November 2018, the two parties signed a MOU on the BRI cooperation. During Xi's visit in the Philippines in November 2018 - the first state visit of a Chinese president since 2006, Duterte welcomed more BRI projects. However, he stressed that they should be "based on the principles of transparency and adherence to international law" and in line with "proper procedures and requirements" ${ }^{18}$. Especially highlighted were infrastructure projects in Luzon, Mindanao and Clark Green City. The opposition, however, accused Duterte of making secret deals with Beijing that threaten to undermine the Philippines' sovereignty, especially as the arbitration should be based on Chinese norms ${ }^{19}$. Tritto and Camba ${ }^{20}$ believe Manila could have negotiated better deals, notably concerning the South Rail, the Chico River Pump irrigation and the Kaliwa dam project. As the example of Malaysia during Prime Minister Mahathir Mohamad's second term reveals, it is possible to renegotiate BRI project terms. However, Manila lacks Putrajaya's negotiation power, as the Malaysian BRI projects are of utmost strategic importance for Beijing, notably the East Coast Railway Link, and Mahathir was respected as an influential elder statesman.

Overall, the Philippines stands to benefit from increased Chinese investments in the context of the BRI [Rabena, 2018. P. 693]. Yet, the current spread of the Coronavirus may negatively impact on China's ability and willingness to further promote BRI projects, at least in the near future. Moreover, to reap economic gains from China, Manila needs to ensure a cost-efficient and corruptionfree implementation [Estrada, 2017].

The Philippines benefits from the strategic rivalry between China on the one hand, the US and Japan on the other hand, as it can reap economic benefits from all three nations. In principle, this strategy provides insurance against becoming economically dependent on the PRC. Apart from donating Official Development Assistance (ODA), Japan also provides soft loans at very good

\footnotetext{
${ }^{15}$ China becomes second biggest foreign investor of Philippines in 2019 // Xinhua. 2020. 2 February. URL: http:// www.xinhuanet.com/english/2020-02/20/c_138801875.htm (accessed 5 March 2020).

${ }^{16}$ Heydarian R. J. What Duterte could learn from Mahathir // Asia Times. 2019. 12 March. URL: https://www. asiatimes.com/2019/03/article/what-duterte-could-learn-from-mahathir/ (accessed 15 May 2020).

${ }^{17}$ Interview with Rodrigo Duterte // RTL. 2017. 22 May URL: https://www.youtube.com/watch?v=Hf6f97X9ntA (accessed 15 April 2020).

${ }^{18}$ President Duterte holds bilateral meetings with President Xi, Premier Li // Republic of the Philippines - Presidential Communications Operations Office. 2019. 25 April. URL: https://pcoo.gov.ph/news_releases/president-duterte-holdsbilateral-meetings-with-president-xi-premier-li/ (accessed 12 April 2020).

${ }^{19}$ Cook M. BRI Risk Reduction // Commentary ISEAS - Yusof Ishak Institute. 2019. URL: https://www.iseas.edu.sg/ media/commentaries/bri-risk-reduction-by-malcolm-cook/ (accessed 16 April 2020).

${ }^{20}$ Tritto A., Camba A. The Belt and Road: The Good, the Bad, and the Mixed // The Diplomat. 2019. 15 April. URL: https://thediplomat.com/2019/04/the-belt-and-road-the-good-the-bad-and-the-mixed/ (accessed 2 April 2020).
} 
terms for infrastructure funding (ports, roads, railways, bridges, the metro in Manila and airports), irrigation, poverty reduction or community development projects. In 2017 Abe and Duterte agreed on financial support and loans worth 9 bil. USD. This support came mostly for infrastructure projects, the disaster-mitigation program and the rebuilding of the city of Marawi ${ }^{21}$. The main outcome of another meeting in Tokyo in October 2018 was the signing of 26 bilateral agreements ( 6 bil. USD), mostly on economic, infrastructure and defence cooperation, including the transfer of technology and equipment ${ }^{22}$. Accordingly, Duterte labelled Japan the Philippine's "biggest helper" ${ }^{23}$. All in all, in the component engagement (political, diplomatic and economic) the Philippines pursues omnidirectional relations with China, the US and Japan to maximize the diplomatic and economic returns from these three nations.

In the security sphere and in particular in regard to responding to China's actions in the South China Sea, Duterte's policies are more contradictious than in the economic realm. Duterte's cautious and, in the beginning, primarily non-confrontational approach towards Beijing is based on his assumption that "China is already in possession [of the South China Sea]. It's now in their hands" ${ }^{24}$. The president argued that it was in order to prevent the outbreak of a war that he is seeking talks with China. Responding to criticism from the opposition, he cautioned that the constitution does not allow the president to give up any territorial claims ${ }^{25}$.

Ensuring both freedom of navigation and access to the resources in the South China Sea seem to be the key, albeit modest aims for Duterte. Regarded in the broader context of the Philippine foreign policy since the year 2000, Duterte's strategy and concrete policies resemble the different approaches of previous presidents towards the PRC. Direct engagement of China is a tool to achieve these goals, as it can lead to jointly developing and sharing the resources with the PRC and subsequently deepening trust and promoting collaboration. This approach to facilitate a dispute resolution is not novel. Rather, it builds on the JMSU and was promoted by Manila during its ASEAN Chairmanship in 2017 as a possible regional trust-building and resolution mechanism ${ }^{26}$. However, it failed to get the approval from China and the other Southeast Asian claimant nations. Beijing also opposed plans to speed up the regional Code of Conduct (COC). At this time, many observers believed that Duterte would settle for a "gentleman's agreement" rather than a legally binding COC to overcome China's opposition ${ }^{27}$. This approach, though, is the mainstream position in ASEAN.

Limited balancing and limited bandwagoning are two other tools a hedging strategy offers. In 2019 and 2020, the responses of the Philippines to China's behaviour in the South China Sea contained elements of these two approaches. In January 2019, Beijing dispatched 275 fishing vessels, a form of "maritime militia", to Thitu (Pag-asa) island to prevent Philippine fishermen from fish-

${ }^{21}$ Yuda M. With its eye on China, Japan pledges $\$ 9$ billion in Philippine aid // Nikkei Asian Review. 2017. 2 November. URL: https://asia.nikkei.com/Politics/With-its-eye-on-China-Japan-pledges-9-billion-in-Philippine-aid (accessed 9 April 2020).

${ }^{22}$ Galang M. A. A Decade of Philippines-Japan Strategic Partnership // The Diplomat. 2019. 26 April. URL: https://thediplomat.com/2019/04/a-decade-of-philippines-japan-strategic-partnership/ (accessed 29 April 2020).

${ }^{23}$ Hynd A. M., Sanchez A. With US out of favour and China doubts, Duterte turns to Tokyo // The Interpreter - Lowy Institute. 2019. URL: https://www.lowyinstitute.org/the-interpreter/us-out-favour-and-china-doubts-duterte-turns-tokyo (accessed 3 May 2020).

${ }^{24}$ Media Interview with President Rodrigo Roa Duterte // Republic of the Philippines - Presidential Communications Operations Office. 2018. 15 November. URL: https://pcoo.gov.ph/media-interview/media-interview-with-presidentrodrigo-roa-duterte/ (accessed 12 April 2020).

${ }^{25}$ Rodrigo Duterte interview: Death, drugs and diplomacy // Al Jazeera. 2016. 16 October. URL: https://www. aljazeera.com/programmes/talktojazeera/2016/10/exclusive-rodrigo-duterte-war-drugs-161015100325799.html (accessed 20 April 2020).

${ }^{26}$ Laude J. Defense chiefs back freedom of navigation in South China Sea" // The Philippine Star. 2017. 25 October. URL: https://www.philstar.com/headlines/2017/10/24/1752200/defense-chiefs-back-freedom-navigation-south-china-sea (accessed 3 June 2020).

${ }^{27}$ Lee-Brago P. Philippines seeks gentleman's agreement on sea code // The Philippine Star. 2017. 21 May. URL: http://www.philstar.com/headlines/2017/05/21/1701969/philippines-seeks-gentlemans-agreement-sea-code (accessed 15 May 2020). 
ing ${ }^{28}$. Unlike in a previous crisis, Duterte responded harshly - evidence for limited balancing. Fully acknowledging the power asymmetries, he said "he would ask the military to "prepare for suicide missions' if the Chinese dare venture into Pag-asa" ${ }^{29}$. Although these comments were made during the campaign for the mid-term elections in May 2019, China may have gone too far with its provocations. Anti-Chinese sentiments put the government under pressure to act or at least speak out strongly against perceived Chinese assertiveness. This invoking of the security pact with the US and Duterte's request on "America to gather all their $7^{\text {th }}$ Fleet in front of China", though, was later dismissed by Duterte as sarcasm ${ }^{30}$.

Interestingly, in response to Chinese assertiveness, in 2019 Manila referred a few times to the award of the Arbitral Tribunal. Officially, it has never shelved the award, but wanted to wait for the "right time" to discuss it with Beijing. The correct argument of foreign minister Teodoro Locsin Jr. is that the award "remains unenforceable because no foreign force seems persuaded to help us enforce it" ${ }^{31}$. Accordingly, the Duterte administration "appears to be cautiously hedging by discarding the PCA ruling in The Hague and deescalating public criticisms of Beijing's foreign policy" [Regilme Jr., Salvador, 2018. P. 225]. A stronger emphasis on the award, though, could signal a move towards stronger balancing against the PRC.

The two protest notes filed by the Philippine foreign ministry in April 2020 against Chinese actions in the South China Sea confirm this observation. The ministry accused the PRC of violating international law and the Philippines' sovereignty: in February 2020, a Chinese ship supposedly pointed its gun control director toward a Philippine ship in an area close to Commodore Reef. The other event was China's establishment of two new administrative zones in the South China Sea in Sansha City (an islet), namely Xisha (Paracel Islands) and Nansha district (Spratly Islands) ${ }^{32}$.

The critical position of the Philippine elites and the broader public on China makes it politically difficult for Duterte to compromise on Manila's legal claims. For Philippine citizens, the South China Sea dispute is the most crucial lens for perceiving China and the BRI fears; falling in a debt trap is another major concern. The political elites have close connections to the former Colonial US power which is also an important investor, source of remittances and ODA donor. American culture and English language are widespread in the predominantly Catholic country. Many high-ranking militaries were trained in the US. The pro-US and China-critical public opinion thus serves as an additional corrective for bandwagoning with the PRC.

The Philippines' capacities for internal balancing against China are severely restricted. The Lowy Institute's comprehensive Asia Power Index (2020), consisting of military, economic, diplomatic and cultural indicators, lists the Philippines as the $17^{\text {th }}$ strongest power in Asia. In the last decade, the Philippines spent annually only 1.1 per cent of its GDP on defence. The Philippine navy has no submarines, but three frigates, ten corvettes and 39 patrol vessels. Also comparatively weak is the air force. As part of its modernization program, before 2022, Manila plans to buy twelve multirole combat aircrafts, twelve FA-50 light fighter aircrafts from South Korea (twelve are already in use) and attack helicopters. The main partners are the US, Indonesia, South Korea and European nations ${ }^{33}$. With this procurement policy, the Philippines gradually shifts from internal defence to

\footnotetext{
${ }^{28}$ Valencia M. J. The standoff at Sandy Cay in the South China Sea // East Asia Forum. 2019. 24 May. URL: https://www.eastasiaforum.org/2019/05/24/the-standoff-at-sandy-cay-in-the-south-china-sea/ (accessed 18 May 2020).

${ }^{29}$ Romero A. Duterte asks China: Don't touch Pag-asa Island // The Philippine Star. 2019. 6 April. URL: https:// www.philstar.com/headlines/2019/04/06/1907700/duterte-asks-china-dont-touch-pag-asa-island (accessed 21 April 2020).

${ }^{30}$ Viray $P$. L. Invoking defense pact with US another 'sarcastic' remark from Duterte - Palace // The Philippine Star. 2019. 18 July. URL: https://www.philstar.com/headlines/2019/07/18/1935782/invoking-defense-pact-us-another-sarcastic-remark-duterte-palace\#GoshKdVWtWlYucem.99 (accessed 29 April 2020).

${ }^{31}$ Romero A. Palace: Arbitral ruling "never shelved" // The Philippine Star. 2019. 14 April. URL: https://www. philstar.com/headlines/2019/04/14/1909998/palace-arbitral-ruling-never-shelved (accessed 21 April 2020).

${ }^{32}$ Cruz de Castro R. Implications of the recent Philippines-China naval stand-off // AMTI. 2020. 7 May. URL: https://amti.csis.org/implications-of-the-recent-philippines-china-naval-stand-off/ (accessed 2 April 2020).

${ }^{33}$ Asia Power Index // Lowy Institute. URL: https://power.lowyinstitute.org/ (accessed 3 May 2020).
} 
defending its territory against outside forces. The message - the political willingness to establish a "credible defence capability" - is directed both towards the PRC and Philippine citizens ${ }^{34}$.

Yet, it is unlikely that Manila's internal balancing measures are able to restrict Beijing's freedom of action in the South China Sea. External balancing therefore seems to be a more reasonable option. The most important insurance against Chinese aggression is the MDT with the US which, as the American Secretary of State Mike Pompeo confirmed in March 2019, also covers the South China Sea area ${ }^{35}$. Although Duterte criticizes the US, the relations, including security collaboration, remained strong in the beginning, exemplified in upholding the bilateral Enhanced Defence Cooperation Agreement (EDCA). One reason is that Manila heavily relies in its fight against terrorism and separatism on US intelligence and weapons. The very first joint military drill of the Philippines with the US, India and Japan in May 2019 was a strong demonstration to secure freedom of navigation in the South China Sea ${ }^{36}$. In addition, up to 300 joint exercises with the US were conducted annually. However, in February 2020, Duterte's surprising termination of the Visiting Forces Agreement (VFA) raised a big question mark over joint future drills and the operational capability of the US troops in the Philippines - and thus the security collaboration with Washington in general. Many Philippine experts criticized this move ${ }^{37}$, and not even all ministers seemed to endorse the termination ${ }^{38}$. Richard Heydarian even claims that Duterte "largely lacks unilateral power to dictate the country's foreign and defence policy" ${ }^{39}$. In June 2020, Duterte responded to the criticism and postponed the decision to terminate the VFA until the end of 2020.

More stable is the Philippine-Japanese security cooperation. Despite the constitutional restrictions on Japan's security policy (Article 9 of the constitution), Tokyo cooperates closely with Manila in the security domain, notably in maritime security, including coastal surveillance ${ }^{40}$. Under the frame of their strategic partnership, the Philippines and Japan jointly conduct regular naval maneuvers and Japan donated, inter alia, ten coast guard vessels ${ }^{41}$. In February 2020 the two nations signed a contract on the procurement of two modern multirole response vessels for the Philippine Coast Guard ${ }^{42}$. Japan is thus a reliable key security partner.

In January 2020, the coast guards of the Philippines and China conducted their very first joint exercise. The maneuvers could be interpreted both as a first step to direct engagement or limited bandwagoning. A more obvious example for limited bandwagoning is the fact that the award of the

${ }^{34}$ Cruz de Castro R. The Next Phase of Philippine Military Modernization: Looking to External Defense // AMTI Update. 2018. URL: https://amti.csis.org/the-next-phase-of-philippine-military-modernization-looking-to-external-defense/ (accessed 1 April 2020).

${ }^{35}$ Panda A. With New South China Sea Tensions With Philippines, China Overplays Its Hand // The Diplomat. 2019. 15 April. URL: https://thediplomat.com/2019/04/with-new-philippine-tensions-china-overplays-its-hand/ (accessed 1 April 2020).

${ }^{36}$ Johnson J. Japan's Izumo helicopter carrier drills with U.S., India and Philippine militaries in disputed South China Sea // The Japan Times. 2019. 9 May. URL: https://www.japantimes.co.jp/news/2019/05/09/national/japan-izumodrills/\#.XPvEuf7gqyp (accessed 17 May 2020).

37 Bautista J. Enforcement of arbitral award is PH core interest // The Manila Times. 2020. 21 March. URL: https://www.manilatimes.net/2020/03/21/opinion/columnists/enforcement-of-arbitral-award-is-ph-core-interest/704603/ (accessed 12 May 2020).

${ }^{38}$ Gutierrez J., Gibbons-Neff T., Schmitt E. Philippines Tells U.S. It Will End Military Cooperation Deal // New York Times. 2020. 11 February. URL: https://www.nytimes.com/2020/02/11/world/asia/philippines-united-states-duterte.html (accessed 3 March 2020).

${ }^{39}$ Heydarian R. J. Change and continuity in the Philippine-US-China triangle // East Asia Forum. 2020. 11 May. URL: https://www.eastasiaforum.org/2020/05/11/change-and-continuity-in-the-philippine-us-china-triangle/ (accessed 15 May 2020).

40 Parameswaran P. Coast guard ship deal highlights growing Japan-Philippine security ties // Japan Times. 2020. 16 February. URL: https://www.japantimes.co.jp/news/2020/02/16/national/politics-diplomacy/coast-guard-ship-dealjapan-philippine-security-ties/\#.XrJ01S1XaqA (accessed 15 May 2020).

${ }^{41}$ Galang M. A. A Decade of Philippines-Japan Strategic Partnership // The Diplomat. 2019. 26 April. URL: https://thediplomat.com/2019/04/a-decade-of-philippines-japan-strategic-partnership/ (accessed 29 April 2020).

${ }^{42}$ Parameswaran P. Coast guard ship deal highlights growing Japan-Philippine security ties // Japan Times. 2020. 16 February. URL: https://www.japantimes.co.jp/news/2020/02/16/national/politics-diplomacy/coast-guard-ship-dealjapan-philippine-security-ties/\#.XrJ01S1XaqA (accessed 15 May 2020). 
Arbitral Tribunal has not been systematically invoked since 2016. The recent references seem to be merely directed towards the Philippine audience. The main illustration for bandwagoning, however, is Duterte's verbally stated acceptance of compromises in the South China Sea dispute in exchange for Chinese investments. This declaration is accompanied by the deliberate loosening of security ties with the US - the only credible security guarantor.

As this contribution demonstrated, since Rodridgo Duterte became president in late June 2016, the Philippines softened its previous hedging approach towards China. Key reasons for his new strategy are the perceptions of China's rising power and the economic benefits offered by the PRC as well as the critical view of the US and the limited strategic leeway of the Philippines. In politics, diplomacy and economics, Manila as the middle power pursues a mix of engaging not only China, but also the potential counterweights - US and Japan. In this regard, the element of continuity remains very strong under Duterte. The Philippines is thus able to maximize the economic benefits from various relationships. In the security domain, notably in the South China Sea dispute, the Duterte administration takes cooperative and, to a lesser extent, confrontative actions toward China. In principle, the applied hedging framework reconciles these apparently contradictious behaviours. Because the overall aim of hedging is to provide insurance against risks and uncertainties resulting from the behaviour of the hedging target through the application of a policy mix; it is only at the first glance inconsistent.

In the case of Duterte's hedging strategy, however, the inconsistencies are considerable. Notably in the defence policy there is no clear pattern. Rather than following a concise strategy, it seems the Philippines is merely reacting to Chinese actions in the South China Sea, deciding in a more or less spontaneous manner whether limited balancing or limited bandwagoning actions are the more appropriate response. Currently, both a limited balancing and limited bandwagoning behaviour can be observed. In early 2020, though, limited balancing against China became stronger. Overall, however, there is a tendency towards stronger bandwagoning with the PRC. The loosing of security relations with the US provides additional significant evidence for a shift to stronger bandwagoning with China. Another important sign is Duterte's linkage of Chinese investments with concessions in the South China Sea dispute. Yet, while the BRI will further promote deeper economic exchange between the Philippines and China, the unresolved South China Sea dispute acts as a corrective for a shift to pure bandwagoning with China. The reason, though, is less Duterte's staunchness to defend Manila's national interests and sovereignty than the China-critical stance of the elites and the broad public which he needs to take into consideration in his China policies. While pure bandwagoning with China should not be expected, the gradual softening of the Philippines' hedging strategy towards China is likely to continue during Duterte's term in office until June 2022.

\section{References}

Baviera A. President Duterte's Foreign Policy Challenges. Contemporary Southeast Asia, 2016, vol. 38, iss. 2, p. 202-208.

Estrada D. V. The Belt and Road Initiative and Philippine Participation in the Maritime Silk Road. Center for International Relations \& Strategic Studies, 2017, vol. 4, iss. 7, p. 4-11.

Gerstl A. The South China Sea Dispute: A Shift to a More Proactive Role in ASEAN's Declamatory Policy and Concrete Policies since 2012? In: Unresolved Border, Land, and Maritime Disputes in Southeast Asia. Bi- and Multilateral Conflict Resolution Approaches and ASEAN's Centrality. Leiden, Boston, Brill, 2017, p. 183-230.

Goh E. Understanding 'Hedging' in Asia-Pacific Security. PacNet, 2006, iss. 43, p. 1-2.

Gong X. The Belt \& Road Initiative and China's Influence in Southeast Asia. The Pacific Review, 2019, vol. 32, iss. 4, p. 635-665.

Haacke J. The Concept of Hedging and its Application to Southeast Asia: a Critique and a Proposal for a Modified Conceptual and Methodological Framework. International Relations of the Asia-Pacific, 2019, vol. 19, iss. 3, p. 375-417. 
Hiep L. H. Vietnam's Hedging Strategy against China since Normalization. Contemporary Southeast Asia, 2013, vol. 35, iss. 3, p. 333-368.

Johnson D. T., Fernquest J. Governing through Killing: The War on Drugs in the Philippines. Asian Journal of Law and Society, 2018, vol. 5, iss. 2, p. 359-390.

Kuik C.-C. Malaysia Between the United States and China: What do Weaker States Hedge Against? Asian Politics \& Polity, 2016, vol. 8, iss. 1, p. 155-177.

Kuik C.-C. The Essence of Hedging: Malaysia and Singapore's Response to a Rising China. Contemporary Southeast Asia, 2008, vol. 30, iss. 2, p. 159-185.

Permanent Court of Arbitration. PCA Case N 2013-19 in the Matter of the South China Sea Arbitration before an Arbitral Tribunal constituted under Annex VII to the 1982 UNCLOS between the Republic of the Philippines and the People's Republic of China. The Hague, PCA, 2016. URL: https://pca-cpa.org/wp-content/uploads/sites/175/2016/07/PH-CN-20160712-Award.pdf (accessed 29 April 2020).

Rabena A. J. The Complex Interdependence of China's Belt and Road Initiative in the Philippines. Asia \& The Pacific Policy Studies, 2018, iss. 5, p. 683-697.

Regilme Jr., Salvador S. F. Beyond Paradigms: Understanding the South China Sea Dispute Using Analytic Eclecticism. International Studies, 2018, vol. 55, iss. 3, p. 213-237.

Walt S. M. The Origins of Alliances. Ithaka, Cornell University Press, 1987, 336 p.

Waltz K. N. Theory of International Politics. Reading, Addison-Wesley, 1979, 256 p.

Материал поступил в редколлегию

Received

15.07.2020

\section{Information about the Author}

Alfred Gerstl, PhD (Political Science), Department of Asian Studies, Palacký University (Olomouc, Czech Republic)

alfred.gerstl@upol.cz

ORCID 0000-0002-1193-3186

Scopus 56682898200

\section{Сведения об авторе}

Герстль Альфред, доктор философии (политические науки), департамент азиатских исследований, Университет Палацкого (Оломоуц, Республика Чехия)

alfred.gerstl@upol.cz

ORCID 0000-0002-1193-3186

Scopus 56682898200 